\title{
EURRECA: qualitative analysis on possible explanations for the variation among European vitamin $B_{12}$ recommendations for the elderly
}

\author{
E. L. Doets, L. S. de Wit, A. E. J. M. Cavelaars, R. A. M. Dhonukshe-Rutten, P. van't Veer \\ and C.P. G. M. de Groot \\ Wageningen University, Division of Human Nutrition (Bode 62), PO Box 8129, 6700 EV Wageningen, The Netherlands
}

Most European countries have national recommendations on micronutrient intakes for the elderly that reflect the level of intake that would meet the requirements of practically all healthy individuals in a specific population. They are used for assessing adequacy of dietary intakes and planning desirable dietary intakes ${ }^{(1)}$.

For the elderly vitamin $\mathrm{B}_{12}$ is a micronutrient of concern since inadequate intakes or poor status are prevalent in Europe and associations with severe health problems such as neurological diseases have been demonstrated ${ }^{(2)}$.

To identify current recommendations on vitamin $\mathrm{B}_{12}$ intake for the elderly, relevant reports from thirty-one European countries and organisations were collated. In addition, a questionnaire was distributed among key individuals and organisations in the different countries to obtain more information on the methods used to derive recommendations. Eight (groups of) countries and organisations derived de novo recommendations, based on the available scientific evidence. ${ }^{(3-10)}$ Other countries adopted values from another source or a combination of sources $^{(1)}$.

In these eight 'original' reports recommendations on vitamin $B_{12}$ intake in Europe vary from $1.4 \mu \mathrm{g}$ to $3.0 \mu \mathrm{g}$. This heterogeneity is confusing for policy-makers, health professionals, industry and consumers. A standard approach for deriving micronutrient recommendations throughout Europe has not yet been possible. National bodies use their own practices often involving small and select committees of experts. Furthermore, cultural and regional factors may affect their weighting of the scientific evidence and influence their decisionmaking.

To pinpoint possible explanations for the variation among vitamin $\mathrm{B}_{12}$ recommendations in Europe, different aspects of the methodology used for deriving them were compared, including: the process of converting physiological requirements into recommendations for populations and how these were defined; whether biomedical factors were considered; how adequacy was assessed; the quality of the evidence base; any other assumptions made.

All eight reports expressed vitamin $B_{12}$ recommendations as the average physiological requirement +2 SD. However, definitions of elderly individuals and consideration of their health status differed between reports. Upper age-groups (years) were defined as $>18$, $>19$, $>51,>65,>71$ and $>75$ and only the report of the DACH countries (Germany, Austria and Switzerland) gave a specific recommended intake for severe atrophic gastritis. Assessments of adequacy used different health outcomes and cut-off values were not the same. All reports assumed that requirements for vitamin $B_{12}$ do not change with age, but different calculations were made to estimate requirements. The scientific evidence base for vitamin $\mathrm{B}_{12}$ recommendations also differed between reports, as judged by a comparison of references cited in three reports published between 2000 and 2003: France; the DACH countries; The Netherlands. Only one 'common' reference was included in all three reports.

The EURRECA-Network of Excellence will estimate vitamin $B_{12}$ requirements of the elderly by systematically reviewing the scientific evidence on the relationship between intake, status and health of the elderly in Europe. The results will contribute to the information required to produce the EURRECA toolkit, which will help to harmonise approaches for setting nutrient recommendations.

1. Doets EL, de Wit LS, Dhonukshe-Rutten RAM et al. (2008) Eur J Nutr 47, Suppl. 1, 17-40.

2. World Health Organization (2002) Diet, Nutrition and the Prevention of Chronic Diseases: Report of a Joint WHO/FAO Expert Consultation. Geneva: WHO.

3. German Nutrition Society (DGE), Referenzwerte fur die Nahrstoffzufuhr / Reference values for Nutrient Intake, in 1st edition in German, German Nutrition Society (DGE), et al., Editors. 2000: Frankfurt/Main: Umschau/Braus.

4. World Health Organization (WHO) and Food and Agriculture Organization of the United Nations (FAO), Vitamin and mineral requirements in human nutrition, in Second edition of report of a joint FAO/WHO expert consultation, Bangkok, Thailand. 2004: Geneva.

5. Panel on DRVs of the Committee on Medical Aspects of Food Policy (COMA), Dietary reference values (DRVs) for food energy and nutrients for the UK, in Report on Health and Social Subjects 41. 1991.

6. Guéguen L et al., The "Apports nutritionnels conseillés" (ANC) for the French population (chapter 2), A. Martin, Editor. 2001, French Food Safety Agency (AFSSA) Paris.

7. Commission of the European Communities, Nutrient and energy intakes for the European Community, in Reports of the Scientific Committee for Food. Thirty first series. 1993: Luxembourg.

8. Nordic Council of Ministers, Nordic Nutrition Recommendations: Integrating nutrition and physical activity, in 4th edition. 2004: Copenhagen.

9. Latvian Food Center (LFC) and Nutrition Council, "Ieteicamās enerğijas un uzturvielu devas Latvijas iedzīivotājiem (IEUD)" ("Recommended Intake of Energy and Nutrients for Latvians / recommended intake of energy and nutrients for Latvians. 2001.

10. Health Council of the Netherlands, Dietary Reference Intakes: vitamin B6, folic acid, and vitamin B12, in publication no. 2003/04. 2003: The Hague. 